УДК 37.015.311:[124.5:17.022.1]

DOI: $10.37026 / 2520-6427-2021-106-2-77-83$
Юрій ПЕЛЕХ,

доктор педагогічних наук, професор, проректор Рівненського державного гуманітарного університету,

м. Рівне, Украӥна

ORCID: 0000-0002-1737-4557

e-mail:pelekhyurii@ukr.net

Андрій МАТВІйЧУк,

доктор філософських наук, професор,

професор кафедри конституиійного права

та галузевих дисииплін

Національного університету

водного господарства та природокористування,

м. Рівне, Украӥна

ORCID: 0000-0002-0008-8589

e-mail:amvriv06@ukr.net

Тамара БІЛОУС,

кандидат педагогічних наук, дочент,

доцент кафедри практики англійської мови

Рівненського державного гуманітарного університету,

м. Рівне, Україна

ORCID: 0000-0001-7411-4623

e-mail:tamara.bilous@ukr.net

\title{
ЦІННІСНИЙ ІНТЕЛЕКТ ЛЮДИНИ В ОСМИСЛЕННІ І ВИРІШЕННІ СУЧАСНИХ СОЦАЛЬНИХ ПРОБЛЕМ
}

Анотація. У статті запропоновано конструкт ціннісного інтелекту, щзо має теоретичну й практичну перспективу як засіб осмислення й вирішення сучасних соиіальних проблем. Обгрунтовуючи означений конструкт, за основу взято позицію щодо залежності життєдіяльності особистості не лише від рівня засвоєння циінностей, а й від сформованості аксіологічної культури.

Доведено, що однією з важливих передумов життевого успіху, досягнень у суспільному житті традииійно вважається інтелект людини як сукупність психічних пізнавальних прочесів, що забезпечують людині можливість розуміти та змінювати світ. Відповідно ичіннісний інтелект людини детермінується як один із результатів освітньої діяльності, здатність ідентифікувати, розуміти й толерантно сприймати різні иіннісні світи (особистісні, групові, соиіальні), а його формування потрактовано як набуття й засвоєння навичок знаходити такі оптимальні ціннісні патерни взаємин з іншими людьми або сочіальними утвореннями у процесі міжособистісної взаємодї, що створюватимуть ситуацію безпеки $i$ спокою у відповідних взаєминах.

Ключові слова: інтелект, соціальний інтелект, емоиіииний інтелект, иіннісний інтелект, сочіальні конфлікти, аксіологія.

\section{Yurii PELEKH, \\ Doctor of Pedagogy, Professor, \\ Vice-rector of Rivne State \\ University of the Humanities, \\ Rivne, Ukraine \\ ORCID: 0000-0002-1737-4557 \\ e-mail:pelekhyurii@ukr.net}

\author{
Andrii MATVIICHUK, \\ Doctor of Philisophy, Professor, \\ Professor of the Department of \\ Constitutional Law and Sectoral Disciplines \\ of the Educational Scientific Institute of Law \\ of National University of Water \\ and Environmental Engineering, \\ Rivne, Ukraine \\ ORCID: 0000-0002-0008-8589 \\ e-mail:amvriv06@ukr.net

\section{Tamara BILOUS,} \\ PhD in Pedagogy, Associate Professor \\ of the Department of English \\ Language Practice of \\ Rivne State University of the Humanities, \\ Rivne, Ukraine \\ ORCID: 0000-0001-7411-4623 \\ e-mail: tamara.bilous@ukr.net
}




\section{VALUE INTELLIGENCE OF THE PERSONALITY IN SOLVING OF MODERN SOCIAL PROBLEMS}

\begin{abstract}
The general problematic context of the present time (mostly negative and tense) causes a special interest to possible means of removing this negativity and tension.
\end{abstract}

The construct of value intelligence, which has a theoretical and practical perspective as a means of understanding and solving modern social problems, is proposed in the paper.

To substantiate the construct of value intelligence, the position about the dependence of the personality's vital activity on the level of assimilation of values and acceptance of value orientations, as well as the formation and level of axiological culture, which includes the depth of axiological knowledge, is taken as a basis. On the other hand, the thesis of great importance is that the human intelligence as a set of mental cognitive processes, that provide a person with the opportunity to understand and change the world, is traditionally considered to be one of the important prerequisites of life success and achievements in public life.

The formation of value intelligence is interpreted as the acquiring and acquisition of skills to find such optimal value patterns of the relationships with other people, or social formations, which will create a situation of security and peace in the relationships in the process of interpersonal interaction. Value intelligence is considered as a subsystem of a social intelligence. This position agrees with the interpretation of social intelligence as an integral plurality of the forms of non-academic intelligence. The value intelligence of a human is defined as the ability to identify, understand and tolerantly perceive different value worlds (personal, group, social). At the same time, the developed value intelligence becomes an important prerequisite for finding solutions in the value discourse that will satisfy the various parties of possible value collisions and conflicts as much as possible.

The value intelligence is potentially seen as one of the results of educational activities. Based on the task of value intelligence formation, the additional motive and argument for strengthening the axiological component of the educational process comes into being. The position that the formation of humanistic values in modern society is impossible without the development of value intelligence is stood up for.

Key words: intelligence, social intelligence, emotional intelligence, value intelligence, social conflicts, axiology.

Постановка проблеми. Ми живемо у час глобальних змін, що супроводжуються новими викликами як для окремо взятої особистості, так і суспільства загалом. Загальний проблемний контекст змушує суспільство балансувати у популярній нині термінології між «помаранчевою» й «червоною» зонами дискомфортів і дисбалансів духовного (морально-етичного й ціннісного) й матеріального характеру. На цьому тлі вже типовими для нас стають емоційна напруженість, загальна конфліктність, ціннісна дезорієнтація, що зрештою визначають нездатність адекватно й ефективно діяти у площині міжособистісної та соціальної комунікації.
Зважаючи на це, пропонуємо осмислити конструкт ціннісного інтелекту, за яким вбачаємо теоретичну й практичну перспективу як засобу вирішення сучасних соціальних проблем.

Аналіз наукових досліджень і публікацій. Станом на сьогодні у спеціальній літературі достатньо опрацьованими $€$ феномени «інтелект», «соціальний інтелект» та «емоційний інтелект», між якими простежується певний змістовний зв’язок. Так, термін «інтелект» потрактовується як сукупність психічних пізнавальних процесів, що забезпечують для людини можливість розуміти та змінювати світ (Ковальова, 2015, с. 11), утім спеціальні дослідження доводять, що спектр щодо тлумачення цього поняття доволі широкий та виходить за межі суто когнітивної сфери у зв'язку з чим варто згадати праці Джоя Гілфорда (1965), Говарда Гаднера (2007), Марини Холодної (2002) та ін.).

Множинність підходів до феномена інтелекту серед іншого зумовила появу ідеї соціального інтелекту Едварда Трондайка, що згодом набула розвитку в різних концептуальних напрямах, спільним для яких було потрактування такого інтелекту як основи комунікації й соціальної адаптації (зокрема це прослідковується у працях Ганса Айзнека (1995), Ненсі Кантор і Джона Кілстрома (1987)).

Занурення у проблематику комунікативного простору через призму соціального інтелекту призвело до появи конструкту «емоиійний інтелект». Його витоки прослідковуються у працях американських психологів Джона Майєра і Петера Саловея (1993) та їхнього послідовника Деніела Гоулмана (2009), на переконання якого саме емоційний інтелект відіграє питому вагу в мисленні, прийнятті рішень та досягненні успіху. Як наслідок, апологети конструкту «емоційний інтелект» наголошують на необхідності та доцільності його розвитку як вагомого чинника особистісного та професійного зростання.

Крім того, в сучасній науці утвердилося переконання, що в основу життєдіяльності особистості, її самоактуалізації покладено цінності й ціннісні орієнтації (наприклад, такі позиції можливо віднайти у працях Мілтона Рокича (1973), Толкотта Парсонса (2000), Патрісії Грінфілд (2016)). Представники сучасної аксіології послідовно відстоюють позицію, що цінності й ціннісні орієнтації є основою взаємодії людини із навколишнім середовищем (соціальним та природним), визначають іiі життєві стратегії. Водночас у сучасній психологічній та аксіологічній літературі досі відсутній такий конструкт як «ціннісний інтелект», хоча, на наше глибоке переконання, $є$ безліч підстав для теоретичного осмислення його методологічних перспектив.

Мета статті - здійснити концептуалізацію феномена «ціннісний інтелект» та окреслити його потенціал у методологічному дискурсі.

Виклад основного матеріалу дослідження. Розглядаючи виокремлену нами проблему, виклад теоретичного матеріалу розпочнемо із констатації факту про 
включення аксіологічної проблематики до широкого спектру наукових досліджень. Так, особлива увага нині приділяється дослідженню так званих «людиномірних систем» та визнанню специфічного характеру таких досліджень (Пелех, 2014, с. 20). Сучасна аксіологія, перебуваючи у системі філософських наук, сама розгалужується в різних напрямах і взаємодіє з різними філософськими дисциплінами: від метаетики і гносеології до естетики і філософії релігії (Hirose, Olson, 2015). Показово, що німецький філософ Ніколай Гартманн у праці «Етика» (у межах власної теорії моралі) саме етику пов’язує з теорією цінностей. Філософ обгрунтовує позицію про те, що моральні цінності виражають належне, а отже, є для людини вимогою, яку належить виконувати (Гартман, 2002, с. 221). Зі свого боку американець Мілтон Рокич потрактовує цінність як стійку перевагу, надану особистістю чи суспільством певному зразку поведінки, або ж остаточному стану на противагу іншому типу поведінки або стану (Rockeach, 1973).

Історична практика свідчить, що соціальний простір - нашарування життєвих просторів конкретних людей, які керуються у своїх життєвих стратегіях певними цінностями й реалізують сформовані ними ціннісні орієнтації. Свого часу німецький філософ Георг Зіммель у своїх міркуваннях про соціальне обстоював думку, що діяльнісна сторона людської сутності грунтується на установках і ціннісних орієнтаціях, які допомагають людині зробити той чи інший вибір. Фактично активність людини завжди обумовлюється ціннісною складовою, адже саме вона надає сенс самому існуванню людини (Зіммель, 1996).

Подібні думки висловлювали й американські вчені Флоранс Клакхон і Фред Стродбек, відзначаючи, що цінності «надають стрункість і спрямованість різноманітним мотивами людського мислення і діяльності в ході вирішення загальних людських проблем» (цит. за Лебедєвою, 1999, с. 129). Суголосною із означеною тезою є позиція Надії Заріцької, яка справедливо зазначає, що «цінності виступають певним стандартом чи критерієм, який підказує: як себе поводити або чого хотіти; які установки потрібно зберігати; яка поведінка вважається виправданою; яке моральне судження має виноситися; як (за якими параметрами) порівнювати себе з іншими; на які цінності та установки оточуючих потрібно вплинути» (Заріцька, 2014, с. 124). Американський учений Клер У. Грейвз також трактує цінності, як мотиватори людської діяльності, що виводять iï на новий рівень життя (Graves, 1970). Українські та польські науковці, як-от Юрій Пелех та Даніель Кукла, визначають поняття «цінність» як «певний ідеал, еталон, до якого людина прагне впродовж життя і діяльності в суспільстві, та який визначає зміст їі життєдіяльності, будучи водночас як регулятором поведінки, так і генератором нових ідей» (Пелех, Кукла, 2019, с. 71). Отже, цінності фактично несуть у собі організуючий та регулятивний потенціал. Відповідно Мілтон Рокич звертає увагу на те, що цінності не тільки можуть вказувати певні цілі, які варті, аби до них прагнути (термінальні цінності), а й містять переконання стосовно того, що певний спосіб дії є прийнятним (Rockeach, 1973).

Представлені вище думки - лише незначна частина 3 наявних міркувань щодо значення цінностей і ціннісних орієнтацій в індивідуальній і соціальній практиці, що переконливо доводять про справедливість твердження: цінності й ціннісні орієнтації - це основа взаємодії людини з навколишнім середовищем (соціальним та природним) і неабияк впливають на іiі життєву стратегію. Беручи до уваги означену позицію, вважаємо за доцільне запропонувати авторський конструкт поняття «ціннісний інтелект». Обгрунтовуючи свою позицію, пропонуємо ознайомитися 3 представленими нижче міркуваннями.

Однією із важливих передумов життєвого успіху, досягнень у суспільному житті традиційно вважають рівень інтелекту людини. Отож не дивно, що інтелект давно є предметом наукової зацікавленості. Так, дослідники констатують цілий конгломерат різних підходів до розуміння сутності поняття «інтелект», якот: феноменологічний; контекстуальний; біологічний; процесуально-діяльнісний; освітній; інформаційний; функціонально-рівневий; регуляційний; метакогнітивний (Ковальова, 2015, с. 11). Одним із наслідків теоретичного осмислення феномена інтелекту стало виникнення концепції соціального інтелекту.

Вважають, що вперше в науковий обіг термін «соціальний інтелект» упровадив американський філософ і психолог Джон Дьюї, який трактував його як уміння спостерігати та оцінювати соціальні ситуації (Landy, 2006). Станом на сьогодні бачення феномена «соціальний інтелект» об'єднує в собі цілу низку підходів, відповідно до яких це: 1) різноманітність знань про соціальну реальність; 2) знайомство з правилами соціальної взаємодіï; 3) здатність до пізнання інших і самопізнання; 4) розумінням своїх і чужих думок, почуттів і поведінки; 5) здатність керувати реакціями людини; 6) здатність до інтерпретації соціальних ключів; 7) уміння уявити можливі наслідки (Weis, 2008). Зрештою узагальнено соціальний інтелект визначають як здатність будувати 3 іншими людьми ефективну взаємодію, результатом якої $є$ краще пристосування людини в суспільстві (Олпорт, 1998). Соціальний інтелект є підгрунтям практичної діяльності людини в суспільстві, адаптації до мінливих життєвих обставин, розумового вирішення життєвих колізій з укладанням інтелектуального плану як основи подальших практичних дій.

Відзначимо, що соціальний інтелект має вагомий функціональний вимір. У спеціальних дослідженнях зазначається, що особи з розвиненим соціальним інтелектом мають значний потенціал для успішної соціальної адаптації, адже володіють здатностями до здобуття інформації щодо інших людей (наприклад, про їхню поведінку, неочевидний зміст висловлювань), здатні формулювати точні судження про людей, прогнозувати реакції оточуючих і потенційні зміни обставин і змісту комунікації із середовищем (Михайлова (Алёшина), 2001). Принциповим для нас також є момент, на який вказує українська психологиня Світлана Харченко: соціальний інтелект суб'єкта розвивається в межах певного соціокультурною простору, з притаманними йому нормами поведінки та соціальної взаємодії. Також дослідниця наголошує, що «в структурі індивідуального соціального інтелекту є певний репертуар стереотипних способів, прийомів та засобів, які дозволяють встановлювати контакт з іншими людьми та здійснювати оптимальну 
взаємодію і мають засвоюватися у процесі соціалізації» (Харченко, 2016, с. 146). Розвиваючи цю думку, додамо, що основою такого «репертуару» $є$ цінності, адже вони виступають «підгрунтям для осмислення, пізнання та конструювання цілісного образу соціального світу, для регуляції поведінки людини в усіх їі виявах під час ухвалення рішення в ситуації вибору» (Кузьминський, 2011, с. 48). Отже, є підстави стверджувати, що соціальний інтелект як підгрунтя практичної діяльності людини в суспільстві корелює 3 цінностями. Цей момент буде врахований нами і надалі.

Поряд із соціальним інтелектом важливим феноменом для наших міркувань $є$ феномен емоційного інтелекту, практичне осмислення якого почалося ще на початку XX ст. і триває досі (Андреєва, 2011). Упродовж століття в центрі уваги дослідників знаходилися інтелект та емоції, кореляції між ними, а також відношення між феноменами «соціальний інтелект» та «емоційний інтелект».

Американський психолог Деніел Гоулман визнає важливе значення людського інтелекту, адже у реальному житті традиційний коефіцієнт інтелекту показує можливості людини оперувати інформацією і логічними правилами та схемами (Гоулман, 2009). Утім, на переконання вченого, для успішного життя цього недостатньо. Як наслідок, дослідник досить давно вивчає проблематику емоційного інтелекту, що відіграє вагому роль у мисленні, прийнятті рішень та досягненні особистого успіху. На його думку, емоційний інтелект потрактовується як сукупність здатностей до самомотивації, контролю над емоціями, внутрішньої стійкості до розчарувань, здатності до саморегуляції свого настрою, вміння контролювати бажання (прагнення до задоволень), не дозволяти переживанням заважати думати, співпереживати й сподіватися (Гоулман, Маккі, Бояцис, 2012).

Ізраїльський психолог Рувен Бар-Он також використовує поняття «емоційно-соціальний інтелект», яке обгрунтовує як поєднання взаємопов'язаних емоційних i соціальних компетенцій, навичок та фасилітаторів, які визначають наскільки ефективно ми розуміємо та виражаємо себе, сприймаємо інших та співвідносимося 3 ними і справляємося зі щоденними вимогами (Bar-On, 2005). Емоційні та соціальні компетенції, навички та фасилітатори передбачають п'ять ключових компонентів, тісно пов'язаних між собою: 1) саморозуміння (усвідомлення власних емоцій, упевненість у собі, самоповага, самоактуалізація); 2) комунікативний потенціал (емпатія, соціальна відповідальність); 3) власне адаптаційні здібності (уміння вирішувати проблеми, долати труднощі, емоційна лабільність); 4) антистресовий потенціал (стійкість до стресів, самоконтроль); 5) загальний настрій (оптимістичність) (Bar-On, 1997).

Загальним підсумком осмислення феноменів «соціальний інтелект» та «емоційний інтелект» $€$ наукове переконання про те, що бути емоційно та соціально інтелектуальним означає ефективно розуміти та виражати себе, розуміти та добре співвідноситися з іншими, а також успішно справлятися зі щоденними викликами, проблемами і тиском, що грунтується на здатності особистості усвідомлювати себе, розуміти свої сильні та слабкі сторони, конструктивно висловлювати свої думки та почуття.
Тим часом ми знову апелюємо до позиції, що в сучасній науці фактично аксіоматичною є теза про залежність життєдіяльності особистості від рівня засвоєння цінностей та прийняття ціннісних орієнтацій, сформованості ціннісно-смислової сфери, розвиненості ціннісної свідомості й рівня аксіологічної культури. Зважаючи на означене вище, вважаємо правомірним запровадження в обіг поняття «ціннісний інтелект». Відповідно розглядаємо його як підсистему соціального інтелекту. У зв'язку з цим наша позиція суголосна із трактуванням соціального інтелекту як інтегральної множинності форм неакадемічного інтелекту - практичного, соціального, емоційного. Ми також погоджуємося із думкою Оксани Ковальової, яка, говорячи про різні інтелекти, зазначає, що йдеться передусім про когнітивні здібності. «Якщо об’єктом когнітивних процесів соціального інтелекту є поведінка, то емоційного - емоції» (Ковальова, 2015, с. 11). За такої умови об'єктом когнітивних процесів ціннісного інтелекту є цінності. Тобто, з одного боку, йдеться про інтелектуальні (когнітивні) здібності щодо виявлення, накопичення, аналізу й оперування аксіологічними знаннями. Водночас формування ціннісного інтелекту - це набуття й засвоєння навичок знаходити такі оптимальні ціннісні патерни взаємин з іншими людьми або соціальними утвореннями в процесі міжособистісної взаємодії, які створюватимуть ситуацію безпеки і спокою у відповідних взаєминах. Ціннісний інтелект людини детермінуємо як здатність ідентифікувати, розуміти й толерантно сприймати різні ціннісні світи (особистісні, групові, соціальні). Відповідно розвинений ціннісний інтелект постає вагомою передумовою знаходження правильного рішення в ціннісному дискурсі, що може бути максимально використано різними сторонами можливих ціннісних колізій і конфліктів.

Рівень сформованості ціннісного інтелекту особистості визначає іiі здатність до: 1) інтелектуальної діяльності в аксіологічному контексті; 2) розуміння специфіки різних ціннісних дискурсів і вміння здійснювати вмотивований ціннісний вибір на підставі аксіологічних знань і ціннісних переконань; 3) практичної діяльності у зв'язку з певними ціннісними дискурсами (наприклад, громадянським, професійним, родинним тощо). Розвинений ціннісний інтелект є передумовою здійснення позитивної життєвої стратегії, зокрема особистої професійної реалізації. 3 іншого боку, нерозвинений або несформований ціннісний інтелект призводить до ціннісної дезорієнтації, нездатності адекватно й ефективно діяти у відношеннях, що виникають на грунті різних ціннісних світів.

Ціннісний інтелект ми також розглядаємо як сукупність особистих і соціальних здібностей у питаннях прийняття ціннісних рішень, визначення й реалізації ціннісних орієнтацій, що впливає на загальну здатність особи ефективно реагувати на виклики і тиск навколишнього середовища (соціального й природного). Відповідно до цього ми дотримуємося позиції, що належна продуктивна адаптивність та ефективність у соціальній або професійній комунікації $є$ для особистості сукупним високим рівнем розвитку соціального, емоційного й ціннісного інтелекту, що інтегрально визначають ії здатність до розуміння й управління життєвою ситуацією. 
Фактично необхідність розвитку ціннісного інтелекту зумовлена і необхідністю вирішення життєвих ціннісних колізій, і потребами особистісного характеру - ціннісними пошуками, ціннісними переживаннями, пошуками і формуванням індивідуальних ціннісних ієрархій та ціннісних орієнтацій. Варто пам'ятати, що цінності й ціннісні орієнтації можуть змінюватися впродовж життя під впливом різноманітних чинників, тому принципово важливо підготувати особистість до вирішення ціннісних колізій, сформувати вміння адаптуватися до нових ціннісних обставин, уникаючи надмірного емоційного й морального навантаження, ціннісної дезорієнтації.

Щодо методологічної перспективи ціннісного інтелекту, то передусім відзначимо, що, на наше глибоке переконання, становлення гуманістичних цінностей у сучасному суспільстві $€$ неможливим без розвитку ціннісного інтелекту. Контролювати формування й оперувати цінностями та ціннісними орієнтаціями може лише особистість із високим ціннісним інтелектом, тобто особа, яка володіє глибокими аксіологічними знаннями, сформованою ціннісно-смисловою сферою, розвиненою ціннісною свідомістю й високою аксіологічною культурою. У процесі життєдіяльності (соціальної чи професійної комунікації) ціннісний інтелект проявлятиметься насамперед у здатності до ефективного вирішення ціннісних колізій і конфліктів (як внутрішніх, так і зовнішніх). Зважаючи на це, ціннісний інтелект у перспективі розглядається нами як один із результатів освітньої діяльності. Зважаючи на завдання формування ціннісного інтелекту, з'являється додатковий мотив і аргумент щодо посилення аксіологічної складової освітнього процесу. Крім того, актуалізується питання відповідної навчально-виховної діяльності, адже очевидно, що формування ціннісного інтелекту передбачає запровадження спеціально організованого освітнього процесу, поєднання системи академічного навчання 3 інноваційними технологіями здобуття знань. Відповідно знання ми потрактовуємо як результат взаємодіi фізичного (матеріального) світу та світу свідомості особистості, щчо призводить до обов'язкових позитивних змін останньої (курсив - авт.). «Взаємодія цих двох світів реалізується у процесі пізнавальної активності (або просто життедіяльності індивіда) як реакція суб'єкта пізнання на довкілля, під час якої інформація, отримана суб'єктом (індивідом) із навколишнього світу та пропущена через його свідомість, набуває функціонального значення (практичне навантаження), тобто перетворюється на знання» (Матвійчук, 2002, с. 25). Повною мірою окреслений підхід до знання і його здобуття поширюється й на аксіологічні знання, що є основою ціннісного інтелекту.

Висновки. Типовим завданням для науки можна вважати пошуки шляхів і засобів зробити життя людини і суспільства більш позитивним та комфортним. Актуальним це завдання залишається і сьогодні, коли людство стикається з низкою глобальних викликів, що очевидно позначаються на індивідуальному й соціальному житті, зокрема на змісті міжособистісної та соціальної комунікації. Очевидний ії̈ проблемний (і часто негативний і напружений) контекст, що ускладнюється морально-етичними й ціннісними розбіжностями, зумовлює особливу цікавість до можливих засобів зняття вказаного негативу й напруженості. Зважаючи на означене вище, нами і був запропонований конструкт «ціннісний інтелект».

Запроваджуючи на теоретичному рівні означений конструкт, з одного боку, ми берем за основу позицію про залежність життедіяльності особистості від рівня засвоєння цінностей та прийняття ціннісних орієнтації, а також сформованості й рівня аксіологічної культури, що включає глибинні аксіологічні знання. 3 іншого боку, посутньою для нас $є$ теза про те, що однією з важливих передумов життєвого успіху, досягнень у суспільному житті традиційно вважається інтелект людини як сукупність психічних пізнавальних процесів, що забезпечують людині можливість розуміти та змінювати світ.

Ціннісний інтелект ми розглядаємо як підсистему соціального інтелекту. Ціннісний інтелект людини детермінуємо як здатність ідентифікувати, розуміти й толерантно сприймати різні ціннісні світи (особистісні, групові, соціальні). Відповідно до цього розвинений ціннісний інтелект постає вагомою передумовою знаходити рішення у ціннісному дискурсі, що максимально задовольнятимуть різні сторони можливих ціннісних колізій і конфліктів.

Водночас ми усвідомлюємо дискусійний характер цього конструкту, щодо типово теоретичних новацій, а отже, перспективу подальших досліджень в означеному напрямі вбачаємо у всебічному дослідженні цього феномена, його концептуальному розробленні й практичній інтерпретації. Зокрема практично-дослідницького результату (підтвердження) потребує, на наш погляд, система висвітлених у дослідженні теоретичних конструктів. Застосування емпіричного підходу в цій царині - питання подальших наукових розвідок. Очевидно, що міркування колег, зокрема і критичні, неабияк сприятимуть результативності нашого наукового пошуку.

\section{СПИСОК ВИКОРИСТАНОЇ ЛІТЕРАТУРИ}

Ковальова, О. А. (2015). Проблема визначення поняття «соціальний інтелект» у психологічній науці. Освіта та розвиток обдарованої особистоcmi. № 10. C. 10-14. URL: http://nbuv.gov.ua/UJRN/ Otros_2015_10_4 (дата звернення: 12.04.2021).

Гилфорд, Дж. (1965). Три стороны интеллекта. Психология мылиления: сборн. переводов. Москва: Прогресс. С. 433-456.

Гарднер, Г. (2007). Структура разума: теория множественного интеллекта. Москва: ООО «И.Д. Вильямс». $512 \mathrm{c.}$

Холодная, М. А. (2002). Психология интеллекта: парадоксы исследования. 2-е изд., перераб. и доп. Санкт-Петербург: Питер. 272 с.

Айзенк, Г. Ю. (1995). Интеллект: новый взгляд. Вопросы психологии. № 1. С. 112-116.

Cantor, N., Kihlstrom, J. F. (1987). Personality and social intelligence. Englewood Cliffs, NJ: Prentice-Hall.

Mayer, J. D., Salovey, P. (1993). The Intelligence of emotional intelligence. Intelligence. № 17 (4). Pp. 433-442.

Гоулман, Д. (2009). Эмоциональный интеллект. Москва: АСТ. 478 с.

Rockeach, M. (1973). The nature of Human Values. New York: Free Press. 438 p. 
Парсонс, Т. (2000). О структуре социального действия. Москва: Академический проект. 880 с.

Greenfield, P. M. (2016). Social change, cultural evolution and human development. Current Opinion in Psychology. № 8. Pp. 84-92.

Пелех, Л. Р. (2014). Теорія і методика аксіологічної освіти в Польщі: порівняльний аспект: монографія. Рівне: ДМ. 401 с.

Hirose, I., Olson, J. (2015). The Oxford Handbook of Value Theory (Oxford Handbooks). New York: Oxford University Press.

Гартман, Н. (2002). Этика. Санкт-Петербург: Владимир Даль. 708 с.

Зиммель, Г. (1996). Как возможно общество? Избранное: в 2 т. Т. 2. Созерцание жизни. Москва: Юрист.

Лебедева, Н. М. (1999). Введение в этническую и кросскультурную психологию. Москва: Ключ-С. 224 с.

Заріцька, Н. Ю. (2014). Зміна смисложиттєвих цінностей як передумова появи альтернативних стилів життя, заснованих на добровільній мобільності. Грані. № 2. C. $123-126$.

Graves, C. W. (1970). Levels of Existence: an Open System Theory of Values. The Journal of Humanistic Psychology. № 10 (2). Pp. 131-155.

Пелех, Ю., Кукла, Д. (2019). Система цінностей майбутнього фахівця і його місце на сучасному ринку праці. Рівне: «Волинські обереги». 184 с.

Landy, F. J. (2006). The long, frustrating and fruitless search for social intelligence: a cautionary tale. A critique of emotional intelligence: what are the problems and how can they be fixed? / K. R. Murphy (ed.). New Jersey: Lawrence Erlbaum Associates. Pp. 81-123.

Weis, S. (2008). Theory and measurement of social intelligence as a cognitive performance construct: dissertation zur erlangung des akademischen grades doktor der philosophie. Magdeburg. URL: http://diglib.uni-magdeburg.deDissertationen/2008/suzweis.pdf (Date of access: 30.03.2021).

Олпорт, Г. (1998) Личность в психологии. Москва: КСП+. 345 с.

Михайлова (Алёшина), Е. С. (2001). Тест Дж. Гилфорда и М. Салливена. Диагностика социального интеллекта. Руководство пользователя. Санкт-Петербург: ГП «Иматон». $56 \mathrm{c.}$

Харченко, С. В. (2016). Роль умов соціалізації в розвиненні соціального інтелекту особистості. Право i Безпека. № 2. С. 146-151.

Кузьминский, А. И. (2011). Ценностные ориентиры современного образования. Ценности профессиональной деятельности современного педагога: межвузовский сборник научных трудов / под общ. ред. М. И. Лукьяновой, Е. А. Лодатко. Черкассы; Ульяновск: УИПКПРО. С. 47-55.

Андреева, И. Н. (2011). Эмоциональный интеллект как феномен современной психологии. Новополоцк: ПГУ. 388 с.

Гоулман, Д., Макки, Э., Бояцис, Р. (2012). Эмоциональное лидерство: искусство управления людьми на основе эмоционального интеллекта; пер. с англ. 6-е изд. Москва: Альпина Паблишер.

Bar-On, R. (2005). Model of emotional-social intelligence. Special Issue on Emotional Intelligence / P. Fernndez-Berrocal and N. Extremera (Guest Editors).
Psicothema. № 17. URL: https://www.researchgate.net/ publication/6509274_The_Bar-On_Model_of_EmotionalSocial Intelligence (Date of access: 30.03 .2021 ).

Bar-On, R. (1997). Emotional Intelligence Inventory (EQ-I): Technical Manual. Toronto: Multi-Health System. Матвійчук, А. В. (2002). Екологічне знання та стиль мислення сучасної науки: монографія. Рівне: Ліста-М. 147 с.

\section{REFERENCES}

Kovalova, O. A. (2015). Problema vyznachennia poniattia «sotsialnyi intelekt» u psykholohichnii nautsi [The problem of defining the concept of «social intelligence» in psychological science]. Osvita ta rozvytok obdarovanoi osobystosti. № 10. S. 10-14. URL: http://nbuv.gov.ua/ UJRN/Otros 2015104 (data zvernennia: 12.04.2021). [in Ukrainian].

Gilford, Dzh. (1965). Tri storony intellekta [Three sides of intelligence]. Psikhologiya myshleniya: sborn. perevodov. Moskva: Progress. S. 433-456. [in Russian].

Gardner, G. (2007). Struktura razuma: teoriya mnozhestvennogo intellekta [The Structure of Mind: Theory of Multiple Intelligences]. Moskva: OOO «I.D.Vilyams». 512 s. [in Russian].

Kholodnaya, M. A. (2002). Psikhologiya intellekta: paradoksy issledovaniya [The psychology of intelligence. Research paradoxes]. 2-e izd., pererab. i dop. Sankt-Peterburg: Piter. 272 s. [in Russian].

Ayzenk, G. Yu. (1995). Intellekt: novyy vzglyad [Intelligence: A New Look]. Voprosy psikhologii. № 1. S. 112-116. [in Russian].

Cantor, N., Kihlstrom, J. F. (1987). Personality and social intelligence. Englewood Cliffs, NJ: Prentice-Hall. [in English].

Mayer, J. D., Salovey, P. (1993). The Intelligence of emotional intelligence. Intelligence. № 17 (4). Rp. 433442. [in English].

Houlman, D. (2009). Emotsionalnyy intellekt [Emotional intellect]. Moskva: ACT. 478 s. [in Russian].

Rockeach, M. (1973). The nature of Human Values. New York: Free Press. 438 p. [in English].

Parsons, T. (2000). O strukture sotsialnogo deystviya [About the structure of social structure]. Moskva: Akademycheskyi proekt. $880 \mathrm{~s}$. [in Russian].

Greenfield, P. M. (2016). Social change, cultural evolution and human development. Current Opinion in Psychology. № 8. Pp. 84-92. [in English].

Pelekh, L. R. (2014). Teoriia i metodyka aksiolohichnoi osvity v Polshchi: porivnialnyi aspect [Theory and methods of axiological education in Poland: comparative aspect]: monohrafiia. Rivne: DM. 401 s. [in Ukrainian].

Hirose, I., Olson, J. (2015). The Oxford Handbook of Value Theory (Oxford Handbooks). New York: Oxford University Press. [in English].

Hartman, N. (2002). Etika [Ethics]. Sankt-Peterburg: Vladimir Dal. 708 s. [in Russian].

Zymmel, H. (1996). Kak vozmozhno obshchestvo? [How society possible?]. Izbrannoe: v 2 t. T. 2. Sozertsanie zhizni. Moskva: Yurist. [in Russian].

Lebedeva, N. M. (1999). Vvedenie v etnicheskuyu i krosskulturnuyu psikhologiyu [Introduction into cross-cultural psychology]. Moskva: Klyuch-S. 224 s. [in Russian]. 
Zaritska, N. Yu. (2014). Zmina smyslozhyttievykh tsinnostei yak peredumova poiavy alternatyvnykh styliv zhyttia, zasnovanykh na dobrovilnii mobilnosti [Changing the meaning of life values as a prerequisite for the emergence of alternative lifestyles based on voluntary mobility]. Hrani. № 2. S. 123-126. [in Ukrainian].

Graves, C. W. (1970). Levels of Existence: an Open System Theory of Values. The Journal of Humanistic Psychology. № 10 (2). Pp. 131-155. [in English].

Pelekh, Yu., Kukla, D. (2019). Systema tsinnostei maibutnoho fakhivtsia i yoho mistse na suchasnomu rynku pratsi [Value system of future specialist and its place in labor market ]. Rivne: Volynski oberehy. 184 s. [in Ukrainian].

Landy, F. J. (2006). The long, frustrating and fruitless search for social intelligence: a cautionary tale. A critique of emotional intelligence: what are the problems and how can they be fixed? / K. R. Murphy (ed.). New Jersey: Lawrence Erlbaum Associates. Pp. 81-123. [in English].

Weis, S. (2008). Theory and measurement of social intelligence as a cognitive performance construct: dissertation zur erlangung des akademischen grades doktor der philosophie. Magdeburg. URL: http://diglib.uni-magdeburg.deDissertationen/2008/suzweis.pdf (Date of access: 30.03.2021). [in English].

Olport, H. (1998). Lichnost v psikhologii [Personality in psychology]. Moskva: KSP+. 345 c. [in Russian].

Mykhailova (Alëshyna), E. S. (2001). Test Dzh. Hylforda y M. Sallyvena. Diagnostika sotsialnogo intellekta. Rukovodstvo polzovatelya [Test by J. Guilford and M. Sullivan. Diagnostics of social intelligence. User's manual]. Sankt-Peterburg: GP «Imaton». 56 s. [in Russian].

Kharchenko, S. V. (2016). Rol umov sotsializatsii $\mathrm{v}$ rozvynenni sotsialnoho intelektu osobystosti [The role of socialization conditions in the development of social intelligence of the individual]. Pravo i Bezpeka. № 2. S. 146-151. [in Ukrainian].

УДК 37.091.12:159.9]:005.336.2

DOI: 10.37026/2520-6427-2021-106-2-83-88
Kuzminskiy, A. I. (2011). Tsennostnye orientiry sovremennogo obrazovaniya. [Value guidelines of modern education]. Tsennosti professionalnoy deyatelnosti sovremennogo pedagoga: mezhvuzovskiy sbornik nauchnykh trudov / pod obshch. red. M. I. Lukyanovoy, Ye. A. Lodatko. Cherkassy; Ulyanovsk: UIPKPRO. S. 47-55. [in Russian].

Andreeva, Y. N. (2011). Emotsionalnyy intellekt kak fenomen sovremennoy psikhologii [Emotional intelligence as a phenomenon of modern psychology]. Novopolotsk: PHU. 388 s. [in Russian].

Houlman, D., Makky, Э., Boiatsys, R. (2012). Emotsionalnoe liderstvo: iskusstvo upravleniya lyudmi na osnove emotsionalnogo intellekta [Emotional Leadership: The Art of Managing People Based on Emotional Intelligence]; per. s angl. 6-e izd. Moskva: Alpina Pablisher. [in Russian].

Bar-On, R. (2005). Model of emotional-social intelligence. Special Issue on Emotional Intelligence / P. Fernández-Berrocal and N. Extremera (Guest Editors). Psicothema. № 17. URL: https://www.researchgate.net/ publication/6509274_The_Bar-On_Model_of_Emotional-Social_Intelligence (Date of access: 30.03.2021). [in English].

Bar-On, R. (1997). Emotional Intelligence Inventory (EQ-I): Technical Manual. Toronto: Multi-Health System. [in English].

Matviichuk, A. V. (2002). Ekolohichne znannia ta styl myslennia suchasnoi nauky [Ecological knowledge and thinking style of modern science]: monohrafiia. Rivne: Lista-M. 147 s. [in Ukrainian].

Дата надходження до редакиіï: 21.05.2021 p.

Тетяна АБРАМОВИЧ,

кандидат педагогічних наук, старший викладач кафедри педагогіки, психології та корекиійної освіти, методист Ресурсного иентру підтримки інклюзивної освіти Рівненського обласного інституту післядипломної педагогічної освіти, м. Рівне, Украӥна

ORCID: 0000-0002-5057-2301

e-mail: t.abramovych@roippo.org.ua

\section{ПСИХОЛОГІЧНА КОМПЕТЕНТНІСТЬ У ПРОФЕСІЙНОМУ РОЗВИТКУ ПЕДАГОГА НОВОЇ УКРАЇНСЬКОЇ ШКОЛИ}

\begin{abstract}
Анотація. У статті зроблено акцент на необхідності психологізації освітнього процесу через підвищення рівня психологічної компетентності всіх його учасників, передусім учителів. Наголошено на важливості прийняття професійного стандарту вчителя, доведено, щзо означений документ не лише
\end{abstract}

регулюватиме фаховий розвиток педагога, а й сприятиме побудові траєкторії його професійного розвитку. Здійснено частковий розгляд професійного стандарту вчителя на прикладі аналізу психологічної компетентності, яка має на меті поєднання низки чинників, зокрема здатність учителя визначати $i$ 